\title{
Peningkatan Hasil Belajar Biologi Siswa Melalui Penerapan Media Video Animasi Tiga Dimensi (3D)
}

\author{
Dharma Ferry $^{1}$, Jepriadi ${ }^{2}$, Dairabi Kamil ${ }^{3}$ \\ ${ }^{1,2,3)}$ Fakultas Tarbiyah dan Ilmu Keguruan, Institut Agama Islam Negeri Kerinci, Sungai Penuh, Indonesia
}

Pengiriman: 18 Nopember 2019; Diterima 24 Nopember 2019: Publikasi: Nopember 2019

\begin{abstract}
Three-dimensional (3D) animation video is one of the media that can be applicated by teachers in the learning process. The use of this media is an alternative for teachers as an effort to improve the learning quality, especially in biology subjects. This study aims to determine the increase in student biology learning outcomes through the application of three-dimensional (3D) animation video media. This research is a classroom action research conducted in two cycles. The research subjects consisted of the students of State Junior High School Number 19 of Kerinci. Data collection techniques through observation and test sheets. Based on the results of data analysis, the average post-test score obtained in the first cycle was 74,94 with the percentage of students achieving Minimum Mastery Criteria (KKM) was $55,5 \%$. In the second cycle, the average post-test score was 81,27 with the percentage of students who reached the minimum mastery criteria (KKM) was $88,8 \%$. The results showed that the application of threedimensional (3D) animation video media influenced the improvement of student biology learning outcomes.
\end{abstract}

Keywords: 3D Animation Video, Biology Learning Outcomes, Learning Media

\begin{abstract}
ABSTRAK: Media video animasi tiga dimensi (3D) adalah salah satu media yang dapat diaplikasikan guru dalam proses pembelajaran. Penggunakan media ini menjadi alternatif bagi guru sebagai usaha untuk meningkatkan kualitas pembelajaran, khususnya pada mata pelajaran biologi. Penelitian ini bertujuan untuk mengetahui peningkatan hasil belajar biologi siswa melalui penerapan media animasi tiga dimensi (3D). Penelitian ini adalah penelitian tindakan kelas yang dilakukan dalam dua siklus. Subyek penelitian terdiri dari siswa SMP Negeri 19 Kerinci. Teknik pengumpulan data melalui lembar observasi dan tes. Berdasarkan hasil analisis data, diperoleh rata-rata nilai post-test pada siklus pertama adalah 74,94 dengan persentase siswa yang mencapai Kriteria Ketuntasan Minimum (KKM) sebesar 55,5\% . Pada siklus kedua diperoleh rata-rata nilai post-test adalah 81,27 dengan persentase siswa yang mencapai Kriteria Ketuntasan Minimum (KKM) sebesar $88,8 \%$. Hasil penelitian menunjukkan bahwa penerapan media video animasi tiga dimensi (3D) berpengaruh terhadap peningkatan hasil belajar biologi siswa.
\end{abstract}

Kata Kunci: Video Animasi 3D, Hasil Belajar Biologi, Media Pembelajaran

*Penulis Korespondensi:

Alamat surel: dharmaferry@iainkerinci.ac.id 


\section{PENDAHULUAN}

Siswa-siswa mempunyai gaya belajarnya sendiri. Gaya belajar merupakan potensi dasar atau kecenderungan potensi anak. Sangat penting bagi guru memperhatikan beberapa gaya belajar yang berbeda-beda ketika akan merancang pembelajaran, baik itu strategi, metode, media pembelajaran dan aktivitas-aktivitas yang melibatkan peserta didik. Gaya belajar secara umum dibagi menjadi visual, auditorial, dan kinestetik. Perbedaan gaya belajar dapat menunjukkan cara terbaik bagi siswa untuk menyerap informasi lebih cepat. Sebagai seorang guru bisa memahami bagaimana gaya belajar peserta didik, mungkin akan lebih mudah dalam menentukan strategi dalam proses pembelajaran dan bisa memberikan hasil yang maksimal (Deporter dan Hernacki, 2005).

Salah satu upaya yang dapat dilakukan untuk meningkatkan kualitas pembelajaran, dengan melihat gaya belajar siswa tersebut yakni menggunakan media ke dalam kegiatan pembelajaran. Berkenaan dengan media pembelajaran terdapat beberapa manfaat media pembelajaran diantaranya: pengajaran akan lebih menarik perhatian siswa sehingga dapat menumbuhkan minat belajar, bahan pengajaran akan lebih jelas maknanya sehingga dapat dipahami lebih oleh siswa, metode mengajar akan lebih bervariasi, siswa lebih banyak melakukan kegiatan belajar, sebab tidak hanya mendengar uraian guru, tetapi juga aktivitas lain seperti mengamati, melakukan, dan lain sebagainya (Sudjana, 2005).

Fungsi media pembelajaran, salah satunya yaitu memotivasi atau meningkatkan hasil belajar peserta didik. Upaya untuk meningkatkan hasil belajar siswa dalam proses pembelajaran di kelas, pemanfaatan media dalam pembelajaran adalah salah satu alternatifnya. Media yang dapat digunakan diantaranya adalah media animasi. Media animasi adalah rangkaian dari beberapa gambar dengan gerak cepat yang terus menerus memiliki hubungan satu dengan yang lainnya, yang awalnya dari potongan gambar yang digerakkan sehingga terlihat hidup (Adinda dan Adjie, 2011).

Media animasi dibuat dari rangkaian potongan gambar yang terlihat hidup. Media animasi dapat memudahkan guru dalam melakukan proses pembelajaran di kelas dan juga dapat menarik perhatian dan minat siswa lebih karena tampilan media yang dibuat menarik. Penerapan media animasi dalam pembelajaran memiliki hubungan serta pengaruh signifikan terhadap perhatian, ketertarikan, motivasi serta hal lainnya yang ada pada siswa (Anwar, Liliawati dan Utama, 2013). Minat belajar yang tinggi berawal dari motivasi diri pada siswa itu sendiri sehingga berpengaruh positif terhadap hasil belajar, (Nurhasanah, 2016).

Proses pembelajaran biologi adalah suatu interaksi edukatif antara guru, dengan siswa dan antara siswa dengan sesamanya serta antara siswa dengan lingkungan. Interaksi yang bernilai edukatif ini berfungsi untuk mencapai tujuan yang telah dirumuskan sebelum pembelajaran dilakukan (Ferry, 2019). Hasil temuan pada saat observasi menunjukkan bahwa hasil belajar beberapa siswa masih belum memenuhi standarisasi Kriteria Ketuntasan Minimum (KKM) sekolah, khususnya pada mata pelajaran biologi. Penerapan media video animasi tiga dimensi dapat dijadikan alternatif untuk meningkatkan hasil belajar biologi siswa tersebut. Hasil penelitian menunjukkan, 
media video animasi ini dapat berpengaruh positif terhadap hasil belajar siswa pembelajaran ditunjang dengan fasilitas yang baik, yaitu terdapatnya proyektor sehingga dengan menggunakan media pembelajaran yang efektif dan inovatif, salah satunya dengan media animasi dapat diterapkan. Namun dalam proses penerapannya perlu kreativitas dalam membuat rancangan dan model tampilan media berisi materi yang ingin dijelaskan dalam pembelajaran agar menarik dan mudah dipahami (Muslimin, 2017). Dengan melihat permasalahan di atas, tujuan penelitian ini adalah untuk mengetahui peningkatan hasil belajar biologi siswa dengan menggunakan media video animasi tiga dimensi (3D).

\section{METODE PENELITIAN}

Jenis penelitian yang digunakan adalah Penelitian Tindakan Kelas (PTK) dimana suatu kegiatan penelitian ilmiah yang dilakukan secara rasional, sistematis dan empiris reflektif terhadap berbagai tindakan yang dilakukan sejak disusunnya suatu perencanaan sampai penilaian terhadap tindakan nyata didalam kelas yang berupa kegiatan belajar mengajar, untuk memperbaiki dan meningkatkan kondisi pembelajaran yang dilakukan.

Penelitian dilaksanakan di SMP Negeri 19 Kerinci. Subjek penelitian ini adalah siswa kelas VIII B berjumlah 18 orang siswa. Instrumen pengumpul data yang digunakan diantaranya lembar observasi dan soal tes obyektif.

\section{HASIL DAN PEMBAHASAN}

Penelitian ini dilaksanakan dalam dua siklus, siklus pertama dilakukan sebanyak dua pertemuan dan siklus kedua dilakukan sebanyak dua pertemuan. Pada awal pertemuan pertama siklus I, dilaksanakan Pretest untuk mengetahui pemahaman awal siswa mengenai sistem pencernaan pada manusia. Pada akhir setiap siklus I dan II dilakukan Posttest untuk mengetahui tingkat pemahaman siswa pada materi yang telah dipelajari dengan mengguanakan media video animasi.

\section{Siklus I}

Tahapan pelaksanaan pertemuan pertama diawali dengan Pretest. Kemudian peneliti melakukan apersepsi, penyampaian tujuan pembelajaran, pembentukan kelompok diskus, penyajian materi menggunakan media animasi, pengerjaan LKS dan presentasi di depan kelas oleh setiap kelompok, perbaikan dan penguatan jawaban dan di akhiri dengan penarikan kesimpulan. Pelaksanaan pertemuan kedua sama dengan pertemuan pertama namun 30 menit sebelum pemebelajaran siswa mengerjakan posttest. Setelah siswa selesai melakukan posttest siswa diminta untuk menyampaikan kesan dan pesan mengenai proses pembelajaran yang telah dilaksanakan pada siklus I serta hal-hal yang harus diperbaiki untuk proses pembelajaran berikutnya yaitu pada siklus II. Berikut merupakan tahapan penelitian dengan penerapan media animasi dalam pembelajaran:

\section{a. Perencanaan (Planning)}

Sebelum melakukan penelitian, peneliti melakukan observasi di SMP Negeri 19 Kerinci. Peneliti juga melakukan wawancara kepada guru biologi mengenai hasil belajar siswa pada tahun ajaran sebelumnya. Dari hasil observasi juga diperoleh hasil gambaran rata-rata ulangan harian kelas yaitu 69,50 dari 18 siswa dengan nilai 
terendah 55,00 dengan nilai tertinggi 80,00.

Persentase kelulusan yang memenuhi KKM $(\geq 75)$ adalah $44,4 \%$ dari total seluruh siswa (Wawancara Guru Biologi). Selanjutnya peneliti mempersiapkan semua hal yang dibutuhkan selama kegiatan penelitian berlangsung.

Hal-hal yang dipersiapkan antara lain: video animasi sistem pencernaan manusia, kemudian peneliti juga menyiapkan silabus, RPP, LKS, soal tes, dan lembar observasi. Setelah semuanya selesai peneliti memulai penelitian.

b. Pelaksanaan (Acting)

Pelaksanaan pembelajaran siklus I, peneliti memberikan Pretest terdahulu kepada siswa untuk mengetahui seberapa besar pemahaman siswa terhadap materi yang akan dipelajrai. Hasil Pretest dapat dilihat pada tabel berikut:

Tabel 1. Hasil Pretest Siswa

\begin{tabular}{lll}
\hline No & Hasil Belajar & Nilai \\
\hline 1 & Nilai rata-rata & 42,50 \\
2 & Nilai tertinggi & 53 \\
3 & Nilai terendah & 33
\end{tabular}

Sumber: Dokumen Pribadi

Setelah mengerjakan soal Pretest kemudian peneliti melakukan apersepsi mengenai pokok bahasan yang akan dipelajari yang berkaitan dengan kehidupan sehari hari-hari siswa serta menyampaikan tujuan pembelajaran. Selanjutnya peneliti membagi siswa dalam 4 kelompok diskusi.

Setelah selesai diskusi kelompok, peneliti meminta perwakilan kelompok untuk mempresentasikan hasil diskusinya. Setelah melakukan peresentasi peneliti memberikan waktu kepada masing-masing kelompok untuk menanggapi dan menambahkan hasil jawaban dari kelompok lain. Selanjutnya peneliti melakukan perbaikan dan penguatan atas jawaban dan presentasi siswa serta menyampaikan materi tambahan yang berkaitan. Pada akhir pembelajaran peneliti meinta siswa untuk merangkum dan merefleksikan apa yang telah dipelajari.

\section{c. Observasi (Observing)}

Pada tahap ini peneliti dibantu oleh guru biologi sebagai pelaku observer yang bertugas mengamati atau mengobservasi kegiatan yang dilakukan siwa selama mengikuti proses pembelajran berlangsung. Jenis observasi yang dilakukan adalah observasi secara kelompok yaitu observer melakukan pengamatan pada setiap kelompok diskusi siswa.

Berdasarkan lembar observasi siswa yang diamati oleh guru pamong biologi, pada hari pertama yaitu untuk masing-masing item aspek penilaian diperoleh hasil sebagai berikut, untuk perhatian siswa saat proses pembelajaran diperoleh skor sedang, respon siswa terhadap model pembelajaran diperoleh skor sedang, keaktifan siswa diskusi kelompok diperoleh skor rendah, kesungguhan dalam mengerjakan LKS yang diberikan diperoleh skor rendah, perhatian siswa saat pemutaran video animasi diperoleh skor tinggi, motivasi siswa saat mengikuti proses belajar diperoleh skor sedang dan tanggung jawab terhadap hasil diskusi terkait pengerjaan LKS diperoleh skor sedang.

Dari uraian diatas dapat disimpulkan bahwa sebagian besar skor yang diperoleh untuk siklus I pada pertemuan pertama masih dalam kategori sedang. Kemudian untuk lembar observasi pertemuan kedua yaitu untuk masing-masing item aspek penilaian diperoleh hasil sebagai berikut, untuk perhatian siswa saat proses pembelajaran diperoleh skor tinggi, respon siswa terhadap model 
pembelajaran diperoleh skor tinggi, keaktifan siswa diskusi kelompok diperoleh skor sedang, kesungguhan dalam mengerjakan LKS yang diberikan diperoleh skor sedang, perhatian siswa saat pemutaran video animasi diperoleh skor tinggi, motivasi siswa saat mengikuti proses belajar diperoleh skor sedang dan tanggung jawab terhadap hasil diskusi terkait pengerjaan LKS diperoleh skor sedang.

Dari uraian diatas dapat disimpulkan bahwa sebagian besar skor yang diperoleh untuk siklus I pada pertemuan kedua masih sama dengan pertama yaitu kategori sedang.

\section{d. Evaluasi (Evaluating)}

Pada pertemuan kedua yaitu 30 menit sebelum jam pelajaran berakhir dilaksanakan posttest siklus I yang bertujuan untuk mengukur tingkat pemahaman dan pengetahuan siswa pada siklus I. Hasil tes evaluasi pada siklus I dapat dilihat pada tabel berikut:

Tabel 2. Hasil Postest Siklus I

\begin{tabular}{lll}
\hline No & \multicolumn{1}{l}{ Hasil Belajar } & Nilai \\
\hline 1 & Nilai rata rata & 74,94 \\
2 & Nilai tertinggi & 86 \\
3 & Nilai terendah & 66 \\
4 & Jumlah siswa yang mendapat nilai $\geq 75$ \\
5 & Jumlah siswa yang mendapat nilai $\leq 75$ \\
6 & Persentase mencapai KKM \\
7 & Persentase tidak mencapai KKM \\
\hline
\end{tabular}

Sumber: Dokumen Pribadi

Pada tabel di atas dapat kita lihat nilai rata- rata siswa adalah 74,94 , nilai tertinggi 86 , nilai terendah 66, jumlah siswa yang mencapai KKM adalah 10 orang, sedangkan jumlah siswa yang tidak mencapai KKM adalah 8 orang, persentase siswa yang tuntas adalah 55,5\% sedangkan yang tidak tidak tuntas adalah $44,4 \%$.

\section{e. Refleksi (Reflecting)}

Penelitian tindakan kelas pada siklus I sudah dilaksanakan secara baik. Dari data yang diperoleh melalui hasil observasi kegiatan siswa selama proses pembelajaran termasuk dalam kategori tinggi. Hal ini berarti siswa dapat mengikuti proses pembelajaran dengan baik yaitu siswa dapat memperhatikan penjelasan guru, siswa juga terfokus pada video animasi dan siswa dapat melakukan diskusi dan presentasi dengan baik. Selain aktifitas siswa, hasil belajar siswa pada siklus I sudah tergolong baik karena lebih dari 50 $\%$ siswa yang mendapatkan nilai mencapai KKM. Adapun kelemahan pada proses pembelajaran pada siklus I antara lain peneliti masih kurang komunikatif dan kurang santai sehingga siswa merasa tegang saat proses pembelajaran dan peneliti menjelaskan materi masih terburu-buru.

\section{Siklus II}

\section{a. Perencanaan (Planning)}

Pada tahap ini peneliti melakukan perbaikan dari permasalahan yang dijumpai selama proses pembelajaran pada siklus I yaitu peneliti meningkatkan pembelajaran yang komunikatif, santai tetapi serius, penjelasan materi tidak terburuburu.

\section{b. Pelaksanaan (Acting)}

Pada siklus II dilaksanakan proses pembelajaran sebanyak 2 kali pertemuan. Langkah pembelajaran pada siklus II kurang lebih sama pada siklus I yaitu apersepsi, menyampaikan tujuan pembelajaran serta pemutaran video animasi. Kemudian peneliti membagi LKS. Setelah mengamati video animasi peneliti meminta siswa berdiskusi dalam menjawab pertanyaan pada LKS, kemudian mempresentasikan hasil diskusi 
kelompok didepan kelas.setelah presentasi peneliti meminta siswa untuk menanggapi. Selanjutnya peneliti memberikan penguatan atas hasil yang benar dan perbaikan atas ahasil yang salah kemudian peneliti memberikan materi tambahan.

Setelah selasai penyampaian materi, peneliti meminta siswa refleksi proses pembelajaran yang telah dilaksanakan kemudian dilanjut dengan posttest II.

c. Observasi (Observing)

Observasi pada siklus II memiliki kesamaan dengan siklus I. Peneliti dibantu oleh guru biologi sebagai observer yang bertugas mengamati atau mengobservasi kegiatan yang dilakukan siswa selama mengikuti pembelajaran pada siklus II. Jenis observasi yang dilakukan adalah observasi kelompok.

Berdasarkan lembar observasi siswa yang diamati oleh guru pamong biologi, pada hari pertama yaitu untuk masing-masing item aspek penilaian diperoleh hasil sebagai berikut, untuk perhatian siswa saat proses pembelajaran diperoleh skor tinggi, respon siswa terhadap model pembelajaran diperoleh skor tinggi, keaktifan siswa diskusi kelompok diperoleh skor tinggi, kesungguhan dalam mengerjakan LKS yang diberikan diperoleh skor rendah, perhatian siswa saat pemutaran video animasi diperoleh skor tinggi, motivasi siswa saat mengikuti proses belajar diperoleh skor tinggi dan tanggung jawab terhadap hasil diskusi terkait pengerjaan LKS diperoleh skor sedang.

Dari uraian diatas dapat disimpulkan bahwa sebagian besar skor yang diperoleh untuk siklus II pada pertemuan pertama mengalami peningkatan hal ini dapat dilihat dari skor masingmasing item diperoleh skor tinggi. Kemudian untuk lembar observasi pertemuan kedua yaitu untuk masing-masing item aspek penilaian diperoleh hasil sebagai berikut, untuk perhatian siswa saat proses pembelajaran diperoleh skor tinggi, respon siswa terhadap model pembelajaran diperoleh skor tinggi, keaktifan siswa diskusi kelompok diperoleh skor tinggi, kesungguhan dalam mengerjakan LKS yang diberikan diperoleh skor rendah, perhatian siswa saat pemutaran video animasi diperoleh skor tinggi, motivasi siswa saat mengikuti proses belajar diperoleh skor tinggi dan tanggung jawab terhadap hasil diskusi terkait pengerjaan LKS diperoleh skor tinggi.

Dari uraian diatas dapat disimpulkan bahwa skor yang diperoleh untuk siklus II pada pertemuan kedua ini mengalami peningkatan yang sangat signifikan hal ini dapat dilihat dari skor masing-masing item diperoleh skor tinggi.

\section{d. Evaluasi (Evaluating)}

Evaluasi atau posttest siklus II dilakukan diakhir pembelajaran yaitu setelah siwa meyampaikan kesimpulan dan refleksi proses pembelajaran yang telah dilaksanakan. Posttest siklus II dilakukan untuk mengetahui peningkatan hasil belajar siswa terhadap materi yang telah dipelajari. Hasil posttest siklus II dapat dilihat pada tabel berikut:

Tabel 3. Hasil Posttest Siklus II

\begin{tabular}{lll}
\hline No & Hasil Belajar & Nilai \\
\hline 1 & Nilai rata-rata & 81,27 \\
2 & Nilai tertinggi & 92 \\
3 & Nilai terendah & 73 \\
4 & Jumlah siswa yang mendapat nilai $\geq 75$ & 16 \\
5 & Jumlah siswa yang mendapat nilai $\leq 75$ & 2 \\
6 & Persentase mencapai KKM & $88,8 \%$ \\
7 & Persentase tidak mencapai KKM & $11,1 \%$ \\
\hline
\end{tabular}

Sumber: Dokumen Pribadi 


\section{e. Refleksi}

Pelaksanaan penelitian pada siklus II dapat berjalan lebih baik dibandingkan dengan siklus I karena peneliti sudah dapat memperbaiki kelemahan dan kekurangan pada siklus I yaitu peneliti dapat melakukan proses pembelajaran dengan komunikatif, santai tetapi serius, penjelasan materi tidak terlalu cepat. Berdasarkan hasil observasi, aktifitas siswa semuanya termasuk dalam kategori tinggi. Hal ini berarti siswa dapat mengikuti proses pembelajaran dengan baik yaitu bisa memperhatikan penjelasan guru, terfokus pada video animasi, melaksanakan kegiatan diskusi dan presentasi dengan baik.

Berdasarkan hasil posstest dari kedua siklus, pada siklus II mengalami peningkatan yaitu yaitu jumlah siswa yang mencapai nilai $\geq 75$ meningkat sebanyak 16 orang siswa dibanding dengan siklus I yang hanya 10 orang siswa. Presentase ketuntasannya juga mengalami peningkatan yaitu $88,8 \%$ dari yang sebelumnya $55,5 \%$. Nilai rata-rata siswa dan presentase kalulusan siswa sudah mencapai indikator yang peneliti harapkan yaitu $\geq 75 \%$. Sehingga penelitian ini bisa dinyatakan sukses dan bermanfaat bagi siswa.

Hasil penelitian menunjukkan bahwa terdapat peningkatan hasil belajar biologi siswa melalui penerapan media video animasi tiga dimensi (3D). Peningkatan tersebut dilihat dari aspek kognitif dan afektif pada materi sistem pencernaan manusia. Didalam penelitian tindakan kelas atau penelitian pendidikan bertujuan menggambarkan situasi atau kejadian disekitar kelas atau sekolah, atas dasar fenomena atau gejala yang muncul. Beberapa guru peneliti kemudian secara teamwork memberikan treatment dan melakukan observasi, mengamati, merefleksikan, dan menyusun laporan penelitian dalam bentuk pendeskripsian apa yang telah dilakukan dilapangan (Sukardi, 2012).

Sesuai dengan pendapat di atas, dalam penelitian ini peneliti juga melakukan observasi terlebih dahulu ke sekolah secara langsung untuk melihat permasalahan apa yang terjadi pada kegiatan pembelajaran, kemudian peneliti juga melakukan pengamatan singkat terhadap kegiatan pembelajaran, kemudian peneliti dan guru melakukan refleksi terhadap permasalahan yang didapat sehingga dari refleksi tersebut diperoleh hasil penelitian sebgai berikut.

\section{Hasil Belajar}

\section{Aspek Afektif}

Berkaitan dengan media animasi, Mayer dan Moreno mengemukakan bahwa, Animasi merupakan satu bentuk presentasi bergambar yang paling menarik, yang berupa simulasi gambar bergerak yang menggambarkan perpindahan atau pergerakan suatu objek. Penggunaan animasi dalam proses pembelajaran sangat membantu dalam meningkatkan efektifitas dan afisiensi proses pengajaran, serta hasil pembelajaran yang meningkat. Selain itu penggunaan media pembelajaran khususnya animasi dapat meningkatkan daya tarik, serta motivasi siswa dalam mengikuti proses pembelajaran. (Sukiyasa dan Sukoco, 2013)

Sesuai dengan pendapat diatas, aspek afektif siwa dilihat dari kegiatan siswa selama proses pembelajaran berlangsung dengan menggunakan lembar observasi yang diamati pada setiap kelompok diskusi siswa. Dari hasil yang 
diperoleh menunjukkan semua siswa kelas VIII B

SMP Negeri 19 Kerinci dapat mengikuti proses pembelajaran dengan baik yaitu siswa memperhatikan video animasi yang ditayangkan, siswa aktif dalam diskusi kelompok dan siswa mengerjakan LKS dengan baik.

\section{Aspek Kognitif}

Menurut Purwanto, Ada dua jenis standar penilaian yang dapat digunakan oleh guru atau peneliti dalam mengolah hasil penilaian yaitu: Pertama, standar mutlak dimana hasil yang dicapai masing-masing siswa dibandingkan dengan kriteria yang telah ditetapkan sebelumnya. Sebagai contoh untuk dapat lulus dalam suatu tes tertentu, siswa harus menyelesaikan dengan benar sekurang- kurangnya $75 \%$ dari soal-soal yang diberikan, tanpa melihat hasil yang dicapai oleh siswa-siswa lain dalam kelompok yang sama (criterion- referenced evaluation). Kedua, standar relatif dimana hasil yang dicapai masing-masing siswa dibandingkan dengan norma kelompok, yaitu hasil yang dicapai oleh siswa- siswa lain dalam kelompok yang sama (norm-referencedevaluation). Dengan menggunakan standar yang relatif, dapat terjadi bahwa siswa yang persentase jawabannya benar hanya 50\% dinyatakan lulus karena kebanyakan teman- temannya yang lain mencapai angka persentase yang lebih rendah. (Purwanto, 2013 ).

Sesuai dengan teori di atas, berdasarkan hasil post-test terhadap siswa yang dilakukan pada tiap akhir siklus I dan siklus II, maka diperoleh kesimpulan dari hasil belajar siswa dan persentase pencapaian nilai KKM pada tiap-tiap siklus tergambarkan pada grafik berikut ini.

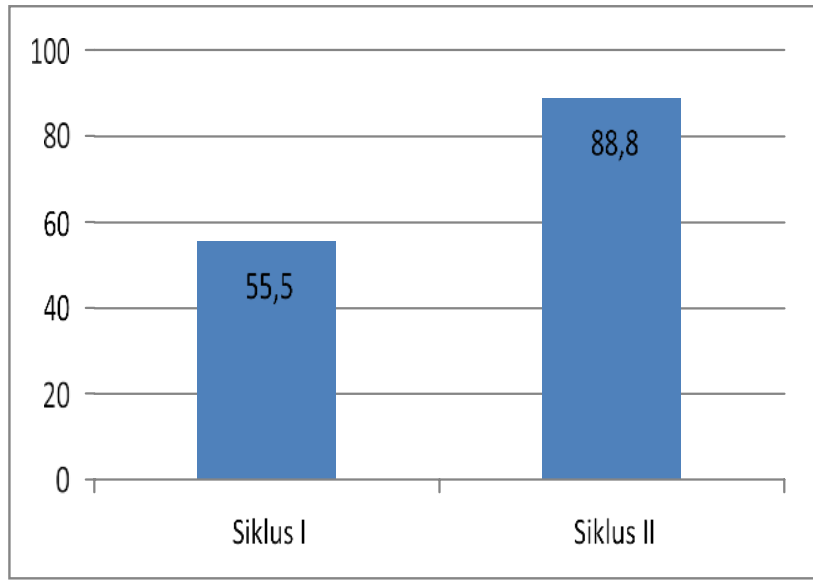

Gambar 1. Grafik Pencapaian \% KKM

Berdasarkan grafik di atas, dapat dilihat perolehan skor rata-rata dan pencapaian KKM. Skor rata-rata siklus I sebesar 74,94 sedangkan skor ratarata siklus II meningkat menjadi 81,27. Dari segi persentase pencapaian KKM menunjukkan adanya peningkatan yang awalnya pada siklus I sebanyak $55,5 \%$ meningkat menjadi $88,8 \%$ pada siklus II. Indikator keberhasilan dalam penelitian ini adalah siswa mencapai nilai ketuntasan minimal $\geq 75$ sebanyak $80 \%$ yang artinya proses proses pembelajaran telah berhasil. Meningkatnya hasil belajar kognitif siswa menunjukkan bahwa secara umum siswa dapat memahami materi sistem pencernaan dibantu dengan menggunakan media animasi.

Hal ini sesuai yang dikatakan oleh Liza Yunita, dalam penelitiannya, suatu pembelajaran dikatakan berhasil apabila sekurang-kurangnya $75 \%$ dari jumlah siswa telah memperoleh nilai 70 dalam peningkatan hasil belajar. Pembelajran dikatakan efektif meningkatkan hasil belajar siswa apabila secara statistik hasil belajar siswa menunjukkan perbedaan yang signifikan antara pengetahuan awal dengan pengetahuan setelah pembelajaran. ( Yunita, 2017)

Dari hasil belajar afektif dan kognitif siswa 
dalam pelajaran biologi materi sistem pencernaan pada manusia setelah proses pembelajaran ini, menunjukkan bahwa penggunaan media video animasi merupakan salah satu media yang tepat. Media video animasi tersebut cocok diterapkan pada materi sistem pencernaan manusia yang banyak hafalannya dan bersifat abstrak terutama pada urutan-urutan sistem pencernaan yang membuat kebanyakan bingung saat mempelajari hal tersebut.

Data pendukung lainnya untuk mengetahui secara langsung dari siswa mengenai hasil belajar yang telah diperoleh yaitu melakukan wawancara yang bersifat subjektif dan dilakukan diluar kegiatan pembelajaran. Berdasarkan hasil wawancara dengan siswa yang dipilih dari siswa yang memiliki nilai tertinggi, sedang dan terendah menunjukkan bahwa ada siswa yang awalnya senang belajar materi biologi dan ada siswa yang kurang senang belajar biologi karena dianggap sebagai materi sulit dan banyak hafalan. Tetapi setelah diterapkan pembelajaran menggunakan media video animasi siswa yang diwawancarai merasa senang dan tertarik untuk belajar dengan menonton video animasi karena materi yang disampaikan dapat dipahami secara baik. Penggunaan media animasi mampu menciptakan suasana pembelajaran yang lebih menyenangkan dan membuat siswa tertarik terhadap pembelajaran, hal tersebut terpengaruh terhadap pemahaman siswa terhadap konsep yang di pelajari dan berpengaruh terhadap hasil belajar siswa. (Khoirunissa, 2017).

Jika ditinjau berdasarkan hasil kognitif ketiga siswa yang diwawancarai, siswa yang memperoleh nilai postest dua tertinggi dan sedang telah memenuhi KKM, kedua siswa tersebut ada yang memiliki semangat belajar yang tinggi yaitu mempelajari kembali materi yang telah dipelajari dan membaca referensi lain yang masih berkaitan dengan materi yang telah dipelajrai dan siswa lainnya memiliki ingatan yang kuat yaitu dapat mengingat kembali materi yang telah dipelajari baik melalui penjelasan peneliti, video animasi yang ditonton dan hasil LKS yang didiskusikan sehingga kedua siswa tersebut dapat mengerjakan posttest dengan baik dan memperoleh hasil yang baik dan memenuhi KKM.

Siswa yang memeperoleh nilai posttest terendah yaitu siswa yang memperoleh nilai yang tidak memenuhi KKM. Siswa tersebut senang dengan pembelajaran yang menggunakan media video animasi tetapi saat pelaksanaan posttest II siswa tersebut kurang siap karena ada permasalahan lain yang sedang diahadapi sehingga berpengaruh pada nilai yang diperoleh dan menyebabkan nilainya tidak memenuhi KKM. Jadi ketidaktercapaian KKM hasil kognitif tidak mutlak dipengaruhi oleh media video animasi yang diberikan. Kemungkinan lain adalah kondisi kesiapan siswa, kosentrasi siswa, cara siswa belajar dan tingkat kecerdasan siswa. Hal ini sesuai dengan yang dikatakan oleh Yunita (2017) dalam penelitiannya mengatakan faktor-faktor yang mempengaruhi hasil belajar banyak jenisnya tetapi dapat digolongkan menjadi dua golongan saja, yaitu faktor internal dan faktor eksternal. Faktor internal adalah yang ada didalam diri individu dan faktor eksternal adalah faktor yang ada diluar individu. (Khoirunissa, 2017)

Adapun permasalahan yang terjadi pada saat penelitian adalah pada saat pembagian kelompok ada siswa yang tidak menerima temannya masuk kedalam kelompok diskusi yang telah 
ditentukan. Solusi dari masalah tersebut diselesaikan dengan cara pendekatan antar siswa sehingga siswa yang bermasalah dapat menerima temannya untuk menjadi anggota kelompok diskusi dan peneliti selalu memantau kelompok tersebut sehingga kelompok diskusi dapat berjalan dengan baik.

Selain itu video animasi yang ditayangkan menurut siswa terlalu cepat sehingga ada beberapa pertanyaan yang belum sempat terjawab. Permasalahan tersebut dapat peneliti selesaikan dengan cara menayangkan ulang video animasi. Permasalahan selanjutnya yaitu kurang jelasnya suara pada video animasi yang di tampilkan karena di kelas tersebut belum ada speaker pengeras suara. Permasalahan tersebut dapat diatasi oleh peneliti dengan cara menuliskan kata dan kalimat serta urutan di papan tulis.

Permasalahan selanjutnya adalah pada saat proses pembelajaran setelah penayangan video animasi masih ada beberapa siswa yang sibuk sendiri dengan mengobrol dengan teman yang lain. Permasalahan tersebut dapat terselesaikan dengan cara tanya jawab yang berkaitan dengan materi yang dipelajari, selain itu peneliti juga langsung menegur dan mengingatkan siswa dengan cara mendekati siswa yang tidak fokus pada kegiatan pembelajaran yang sedang berlangsung.

Seorang guru hendaknya sebagai faktor sentral memegang peranan penting dalam rangka keberhasilan pembelajaran dengan menggunakan media video animasi ini. Dimana seorang guru dituntut menguasai pengetahuan pengelolaan kelas terutama saat proses pembelajaran berangsung agar perhatian siswa terfokus ke materi yang diajarkan. (Rahmatullah, 2011)

\section{KESIMPULAN DAN SARAN}

Berdasarkan penelitian yang telah dilakukan di SMP Negeri 19 Kerinci ditunjukkan bahwa penggunaan media video animasi dapat meningkatkan hasil belajar siswa baik dalam aspek kognitif maupun afektif. Hal ini di buktikan dari hasil belajar aspek kognitif pada siklus I untuk nilai rata-rata adalah 74,94 dan mengalami peningkatan pada siklus II yaitu nilai rata-rata menjadi 81,27. Sedangkan persentase jumlah siswa yang mencapai KKM pada siklus I adalah sebesar 55,5 \% meningkat pada siklus II menjadi 88,8\%. Selain itu hasil belajar siswa aspek afektif pada siklus I maupun siklus II termasuk dalam kategori tinggi.

Berdasarkan hasil yang di dapat tersebut, dapat ditarik kesimpulan bahwa penggunaan media video animasi tiga dimensi dapat meningkatkan hasil belajar biologi siswa kelas VIII B SMP Negeri 19 Kerinci.

\section{DAFTAR PUSTAKA}

Adinda dan Adjie.(2001). Film Animasi 2D Berbasis 3D Menggunakan Teknik Cell Shading Berjudul The Postman Story. STIKOM: Surabaya.

Deporter, B \& Hernacki. 2005. Quantum Learning, Bandung: Kaifa

Ferry, D. (2019). Peningkatan Hasil Belajar dan Keaktifan Mahasiswa Melalui Strategi Pembelajaran Peta Konsep Pada Mata Kuliah Evolusi. Journal on Education, 1(4), 809-816. Retrieved from http://jonedu.org/index.php/joe/article/ view/249

Miftania, A. 2001. Film Animasi 2D Berbasis 3D Menggunakan Teknik Cell Shading Berjudul The Postman Story. Surabaya: STIKOM.

Muslimin, MI. 2017. Pengaruh Penggunaan Media Pembelajaran Video Animasi Terhadap 
Hasil Belajar Pendidikan Kewarganegaraan Kelas II SD. E-Jurnal Prodi Teknologi Pendidikan Vol. VI Nomor 1 Tahun 2017. http://journal.student.uny.ac.id/ojs/index.p hp/fiptp/article/download/6106/5823

Nurhasanah, Siti dan Sobandi. (2016). Minat Belajar Sebagai Determinan Hasil belajar. JPMANPER Journal. Vol. 1. No. 1. Hlm. 135-142. Tersedia di: http://ejournal.upi.edu/index.php/jpmanp er/article/view/3264/2338

Purwanto, N. 2013, Prinsip-prinsip dan Teknik Evaluasi Pengajaran, Jakarta: PT Remaja Rosdakarya.

Sudjana, N \& Rivai, A. 2005. Media Pengajaran. Bandung: Sinar Baru Algesindo

Sukardi. 2013. Metode Penelitian Pendidikan Tindakan Kelas Implementasi dan Pengembangannya, Yogyakarta: PT Bumi Aksara.

Sukiyasa, K \& Sukoco. 2013. Pengaruh Media Animasi Terhadap Hasil Belajar dan Motivasi Belajar Siswa Materi Sistem Kelistrikan Otomotif. Jurnal Pendidikan Vokasi Vol 3 No 1 . DOI: 10.21831/jpv.v3i1.1588

W. S. Anwar, W. Liliawati, J. A. Utama . 2013. Penerapan Pembelajaran Konseptual Interaktif dengan Menggunakan Media Animasi Untuk Meningkatkan Penguasaan Konsep IPBA dan Mengetahui Profil Aktivitas Siswa SMP. WAPFI Journal. Vol. 1. No. 1. DOI:10.17509/wapfi.v1i1.4892

Yunita, L. 2017. Pengaruh Penggunaan Media Animasi Terhadap Aktivitas Dan Hasil Belajar Siswa Pada Materi Sistem Pencernaan di SMP 1 Darussalam. Skripsi. Banda Aceh : Fakultas Tarbiyah Dan Keguruan Universitas Islam Negeri Ar-Raniry Darussalam. 